\title{
A Preliminary Study of Computerized Cognitive Ability Enhancement Program Using Smart-Toy for Children
}

\author{
Min-Sup Shin', Jungeun Lee ${ }^{2}$, Jihyun Lee ${ }^{2}$, Jinjoo Lee ${ }^{2}$, \\ Eunmi Kwon ${ }^{2}$, Hyejin Jeon ${ }^{2}$, and Seunghwan Lee $^{2}$ \\ ${ }^{1}$ Department of Psychiatry and Behavioral Science, Seoul National University College of Medicine, Seoul, Korea \\ ${ }^{2}$ Department of Child and Adolescent Psychiatry, Seoul National University Hospital, Seoul, Korea
}

\author{
스마트 토이를 활용한 아동용 인지능력 증진 프로그램의 예비 효과 연구 \\ 신민섭 ${ }^{1}$, 이정은 ${ }^{2}$, 이지현 ${ }^{2}$, 이진주 ${ }^{2}$, 권은미 ${ }^{2}$, 전혜진 ${ }^{2}$, 이승환 ${ }^{2}$ \\ 서울대학교 의과대학 정신과학교실, ${ }^{1}$ 서울대학교병원 소아청소년정신과 ${ }^{2}$
}

\begin{abstract}
Objectives: This study was to examine the effectiveness of computerized cognitive ability enhancement program (CCAEP) using Smarttoy. The CCAEP using Smart-toy which can interact with children via bluetooth is a kids-friendly and convenient method for improving children's cognitive abilities by increasing their motivation for performing the program. We developed the CCAEP which designed to train auditory-verbal memory, visual-spatial memory, auditory-verbal working memory, and visual-spatial working memory.

Methods: Eighteen children aged 8 to 10 participated in CCAEP individual training composed of 8 sessions of 40 minutes each for 4 weeks. The effect of the training was measured with Smart Toyweb's cognitive assessment tasks (smart device based assessment) as well as traditional neuropsychological tests before and after the training.

Results: Children showed significant improvement in auditory-verbal memory, visual-spatial memory, auditory-verbal working memory and visual-spatial working memory abilities after the training.

Conclusion: This study demonstrated promising results suggesting the effectiveness of CCAEP using Smart-Toy in clinical settings as well as school and home situations. Further controlled study with larger sample size including various clinical groups is needed to confirm the present results.
\end{abstract}

Key Words: Smart-toy; Memory; Working memory; Cognitive training program; School age child.

Received: October 13, 2016 / Revision: November 9, 2016 / Accepted: February 18, 2017

Address for correspondence: Min-Sup Shin, Department of Psychiatry and Behavioral Science, Seoul National University College of Medicine, 101 DaeHak-ro, Jongno-gu, Seoul 03080, Korea

Tel: +82-2-2072-2454, Fax: +82-2-744-7241, E-mail: shinms@snu.ac.kr

서 론

새로운 정보를 습득하고 유지하며, 필요 시 인출하는 능력 을 의미하는 기억력과 현재 입력되는 정보에 주의를 집중하고 이를 머릿속에서 유지하면서 조작하는 능력인 작업기억력은 새로운 정보를 학습하고, 복잡한 일상생활을 영위하는 데 핵 심적으로 작용하는 인지 영역 중 하나라는 점에서 매우 중요 하게 생각되어 왔다. 기존의 연구 결과에 따르면, 기억력과 작 업기억력은 8 세까지 급격하게 증가하다가 11 세나 12 세 이후

This is an Open Access article distributed under the terms of the Creative Commons Attribution Non-Commercial License (http://creativecommons.org/licenses/by-nc/4.0) which permits unrestricted non-commercial use, distribution, and reproduction in any medium, provided the original work is properly cited.
부터는 완만하게 발달하게 되며, 학령기 아동들의 자기 효능 감과 정신건강에 상당한 영향을 미치는 학습능력과 직접적으 로 결부되어 있다..$^{1-3)}$ 이미 다수의 연구에서 반복적이고 체계 적인 훈련을 통해 기억력과 작업기억력을 증진시킬 수 있음이 밝혀져 왔으며, 이는 학령기 아동을 대상으로 한 연구들에서 도 검증되어 왔다. ${ }^{4.5}$ 그러나 인지훈련의 특성상 반복적인 수행 과정이 요구되며, 이로 인해 아동들이 지루해하고 수행 동기가 저하되기 쉽다는 점이 지적되어 왔다. 이에 대한 대안으로 인 지훈련에 게임의 요소를 도입한 시도들이 이루어졌는데 게임 방식은 다양한 문제 상황들이 맥락을 지녀 아동의 문제해결력 을 신장하며, 성취욕구나 동기 수준을 증진할 수 있는 여건과 환경을 제공해준다는 장점이 있다. ${ }^{67}$ 
이에 따라 게임적 요소를 도입한 전산화된 인지훈련 프로 그램들을 개발하고자 하는 시도가 활발하게 이루어져 왔다. 그리고 이러한 프로그램들은 인지기능 측면에서 $\mathrm{IQ}$ 의 증가 (mindsparke), 독창성(lumosity), 학업성취(jungle memory) 에 도움이 된다고 밝혀진 바 있다. ${ }^{89)}$ 특히, 비디오 게임 형식의 Cogmed는 가장 선도적인 위치를 차지하고 있는 전산화된 인 지훈련 프로그램으로 미취학 아동에서 노인까지 다양한 연령 대와 뇌손상이나 attention-deficit hyperactivity disorder $(\mathrm{ADHD})$, 학습 문제가 있는 임상군에서 인지능력 향상에 효 과를 보이는 것으로 나타났으며, 임상 현장은 물론 저조한 학 업성취를 보이는 아동들을 대상으로 부모나 교사에 의해 가 정 및 학교 장면에서도 사용되고 있다. ${ }^{10)}$ 국내에서 개발되어 전문가에 의해 그 효과성이 검증된 인지훈련 프로그램으로는 '브레인 오아시스'가 있다. ${ }^{11)}$ '브레인 오아시스'는 인터넷 웹 기반 의 인지훈련 프로그램으로서, 시청각주의력, 작업기억력, 행동 조절능력 및 조직화 능력 등의 인지 영역을 훈련하도록 고안 되었다. 하지만 전산화된 인지훈련의 효과성에 대한 상반된 결과들이 지속적으로 나타나고 있으며, 인지훈련을 통해 향상 된 인지능력이 훈련되지 않은 다른 영역, 예를 들어 실행 기능 과 같은 측면으로 전이(transfer)되는지에 대한 상반된 견해가 존재하고 있다. ${ }^{5,12,13)}$

기존의 전산화된 프로그램이 인지능력 향상 효과에 대해 비판적인 견해를 보이고 있는 연구자들은 작업기억력이라는 개념이 정보의 유지와 조작이라는 상이한 개념을 포함하고 있으며, 실제로 실행 기능이나 학습능력을 향상시키는 데 보다 직접적으로 관련 있는 것은 정보의 조작 능력임에도 상당수 의 작업기억력 훈련과제가 정보의 유지만을 훈련하는 상당히 단순한 과제들로 구성되어 있었다는 점을 주로 언급하고 있 다. ${ }^{14)}$ 따라서 새로 개발되는 인지훈련 프로그램에서는 정보를 유지하면서 간섭 과제를 수행하거나(dual process) 순서를 재 배열하는(serial reordering) 등 정보를 적극적으로 조작하는 보다 복잡한 과제를 포함할 필요가 있다. 아울러 개별사용자 에게 적절하도록 과제 난이도를 조절하여 제시하면 참여자의 훈련 참여도와 훈련 효과, 훈련 효과의 전이에 긍정적인 영향 을 미칠 수 있다는 연구 결과들이 다수 보고되고 있는 바, 난 이도를 참여자의 능력과 수행에 따라 조절하여 제시할 수 있 도록 할 필요가 있어 보인다. ${ }^{15}$

또한, 기존의 전산화된 인지훈련 프로그램은 인터넷이 연결 된 컴퓨터로만 접속이 가능하여 아동이 주체적으로 이를 휴대 하며 훈련을 받기가 어렵다는 단점이 있었다. 이에 대해서는 접 근이 쉬운 스마트 기기를 활용한 인지훈련 및 교육 프로그램 이 기존의 컴퓨터로 된 인지훈련 프로그램의 좋은 대안이 될 수 있다. 스마트 기기를 활용한 인지훈련 프로그램은 전통적
인 방법에 비해 아동에게 더 높은 동기를 부여하고 흥미를 끈 다는 장점이 있으며 어디서나 위탁 개별화된 훈련을 할 수 있 다. ${ }^{16)}$ 스마트 기기 기반 인지훈련 프로그램을 통해 아동의 학업 성취를 비롯한 인지기능이 더욱 향상되었으며, 특히 특수치료 분야에서 문제해결 전략 등과 같은 보다 고차원적인 인지기능 향상에도 도움이 된다는 연구 결과도 보고된 바 있다. ${ }^{17)}$

그러나 스마트 기기는 일방향적인 지시에 따라 수행이 이루 어지고 있어 사용자를 주어진 정보만 받아들이는 수동적인 존재로 만들며, 타인과의 상호작용을 통한 공감 능력이나 정 서 및 사회적 발달에 부정적인 영향을 미치는 것에 대한 우려 가 지적되었다. 이에 대한 대안으로 아동에게 친근감과 호감 을 주는 로봇을 활용한 치료적 개입이 각광을 받고 있다. ${ }^{18,19)}$ 연구에 따르면 로봇을 활용하면 상호적인 훈련과 학습이 장 려되고 이에 따라 아동들이 활동에 더욱 참여하게 되는데, 이 는 아동이 인지, 행동 및 정서적 특성을 로봇에 부여하여 인 간과 같이 움직이고 반응하는 대상으로 지각하여 친밀감을 느낄 수 있기 때문이라고 한다. ${ }^{20)}$ Toh 등 ${ }^{18)}$ 은 일반 아동에게 도 적용 가능한 로봇을 활용한 훈련 영역을 인지, 지각, 언어 및 사회화 기술의 네 가지 주요 범주로 분류한 바 있다. 이에 따라 국외는 물론 국내에서도 일반 아동의 인지능력 향상을 위한 교육용 로봇의 개발이 활발한 추세로 우리나라에서는 최근 키봇2(KT), 아띠(SKT) 등이 상용화되어 시판되고 있다. 다만 이러한 교육용 로봇은 한글이나 외국어 학습 등 교과 학습 측면에 치중되어 개발되어 있으며 아직까지 인지 능력 향상의 효과를 검증한 연구는 이루어지지 못한 실정이다. ${ }^{21,22)}$

이에 본 연구에서는 컴퓨터 및 스마트 디바이스 기반의 인 지능력훈련 프로그램의 제한점을 보완한 과제를 개발하여 학 령기 아동의 기억력 및 작업기억력의 발달을 체계적으로 도모 하고자 한다. 우선 아동의 수행에 따라 난이도가 조절되도록 고안하였고, 실생활과 유사한 다양한 장면과 상황(예, 버스 정류장, 식당 등)을 설정하였으며, 게임의 요소를 도입하여 아 동이 흥미와 동기를 잃지 않고 자발적으로 과제를 수행할 수 있도록 하였다. 아울러 로봇의 형태로 된 스마트 토이라는 새 로운 스마트 디바이스를 고안하여, 아동이 흥미와 친밀감을 느낄 수 있도록 함은 물론 아동이 수행을 잘하거나 부진한 경 우 스마트 토이가 표정과 말을 통해 아동을 칭찬하거나 위로 하고 도움말을 제공하도록 하는 등 양방향적인 상호작용을 강화하여 아동의 수행에 대한 동기를 유지시키고, 정서 및 사 회적 발달에도 도움을 주고자 하였다. 아울러, 작업기억력 과 제를 단순히 정보의 유지에 그치지 않고, 이를 조작하거나 간 섭 과제를 수행하는 등 보다 복잡한 작업기억력을 수행할 수 있도록 고안하였다. 이에 본 연구에서는 8 10세 아동을 대상 으로 로봇 형태의 토이가 피드백을 제공하는 스마트 디바이 
스 기반 기억력 및 작업기억력 인지훈련 프로그램을 개발하 고, 훈련 전후 인지기능의 평가결과를 비교함으로써 인지능력 향상 효과를 검증하는 예비연구를 실시하였다.

\section{방 법}

\section{대 상}

인터넷 모집공고를 통해 참여를 신청한 만 8 10세에 해당 하는 일반 초등학교에 다니는 아동을 대상으로 하였다. 신청 단계에서 보호자와의 면담을 통해 $\mathrm{ADHD}$ 로 치료 경험이 있는 경우는 배제하였고, 사전 검사 단계에서 단축형 지능검사를 실시하여 전체 지능 추정치가 70점 이하인 지적 장애 아동들 역시 배제되었다. 이에 최종적으로 총 18 명이 연구에 참여하였 다(남아: 10 명, 여아: 8 명, 평균 전체 지능 추정치 $=115 \pm 11.2$ ). 연 구에 참여한 아동들의 연령집단별 표집 수 및 성별, 지능지수 는 Table 1에 제시하였다.

\section{연구 도구}

\section{측정 도구}

8 10세 스마트 토이웹 기억력 평가과제

만 8 10세 아동을 대상으로 스마트 기기를 활용하여 실시 할 수 있도록 전산화 및 자동화된 평가과제이다. 스마트 토이 웹 기억력 평가과제는 총 40 분에 걸쳐 청각언어 기억력, 시각 공간 기억력, 청각언어 작업기억력, 시각공간 작업기억력 등 총 4가지 영역을 측정한다. 이 평가도구의 연령별 수행점수는 이론적으로 잘 알려진 신경인지기능의 발달적 경향성과 부합 하였고, 동일 영역을 평가하는 기존의 표준화된 도구와 경도중등도 이상의 상관을 보이는 등 구성타당도와 공존타당도가 검증되었다. ${ }^{23)}$

한국판 아동용 웩슬러 지능검사(Korea Educational Development Institute Wechsler Intelligence Scale for Children, KEDI-WISC)

만 5세 이상 아동의 인지능력을 평가할 수 있도록 만들어진

Table 1. Participants' characteristic

\begin{tabular}{lccc}
\hline \multicolumn{1}{c}{ Age } & $\mathrm{n}$ & Sex, boy/girl & Estimated FSIQ, M (SD) \\
\hline $8 \mathrm{yrs}$ & 5 & $3 / 2$ & $118(13.7)$ \\
$9 \mathrm{yrs}$ & 7 & $3 / 4$ & $110(9.6)$ \\
$10 \mathrm{yrs}$ & 6 & $4 / 2$ & $119(10.2)$ \\
Total & 18 & $10 / 8$ & $115(11.2)$ \\
\hline
\end{tabular}

Estimated FSIQ: estimated Full Scale Intelligence Quotient, M: mean, n: the number of participants, SD: standard deviation
임상 도구이다. 기억과제의 수행에 영향을 줄 수 있는 지적능 력을 통제하고 지적장애 아동을 배제하기 위하여 단축형 지 능검사를 실시하였다. 단축형 지능은 어휘, 산후, 차례 맞추 기, 토막짜기의 4개 소검사로 Full Scale Intelligence Quotient를 추정하는 Korea Educational Development Institute Wechsler Intelligence Scale for Children(KEDI-WISC) 단 축형 지능 산출공식을 이용하여 산출하였다. 또한 본 연구에 서 개발한 청각언어 기억 및 작업기억 훈련과제와 상관을 보 기 위해, 아동용 웩슬러 지능검사의 '숫자와 '산수' 소검사 측 정치를 사용하였다. 숫자 소검사는 불러주는 숫자를 바로 따 라 외우기와 거꾸로 따라 외우기로 구성되어 있으며, 주의력과 단기 기억능력을 측정한다. 산수 소검사는 청각적 지시를 듣 고 간단한 연산을 수행해야 하는 과제로 청각적 작업기억능 력과 관련이 있다. ${ }^{24)}$

한국판 아동용 루리아-네브라스카 신경심리 검사

(The Korean version of Luria-Nebraska Neuropsychological Test for Children, K-LNNB-C)

만 8 13세 아동들을 대상으로 광범위한 신경심리학적 기능 을 평가하기 위해 제작된 다차원적 검사배터리이다. The Korean version of Luria-Nebraska Neuropsychological Test for Children(K-LNNB-C)의 임상 척도 중 청각언어 기억을 평 가하는 $128,129,131$ 번 문항을 사용하였다. 128 번 문항은 7 개 의 단어들로 구성된 단어목록을 청각적으로 들려주는 시행 을 5 회 반복함으로써, 반복적인 자극제시에 따라 언어적인 학 습이 일어나는지 평가한다. 131 번 문항은 5 개의 단어를 5 초 동 안 시각적으로 제시하고, 5 초 후에 몇 개의 단어를 기억하는 지 평가한다. 129 번 문항은 시각적 도형자극 5 개를 10 초간 보 여주었다가 몇 개의 도형을 회상할 수 있는지 시각 기억력을 평가한다. ${ }^{25}$

레이-오스테리스 복합 도형 검사(Rey-Osterrieth Complex

Figure Test, ROCF)

지각적 조직화와 시각적 기억력 및 계획 능력을 평가하기 위한 목적으로 고안된 신경심리검사이다. 이 검사는 먼저 복 잡한 도형을 보고 그리는 모사 시행, 곧바로 다시 기억해서 그 리는 즉시회상 시행, 20 분 후 다시 기억해서 그리는 지연회상 시행으로 이루어졌다. 레이-오스테리스 복합 도형 검사 한국 판 발달적 채점체계(Korean Developmental Scoring System for the Rey-Osterrieth Complex Figure)에 따라 Rey-Osterrieth Complex Figure Test(ROCF)의 즉시회상 및 지연회상 시 행에서의 정확도 점수를 산출하여 분석에 활용하였다. ${ }^{26)}$ 
코르시 블록 검사(Corsi Block Test)

코르시 블록 검사는 시공간 작업기억력을 측정하기 위해 사 용되는 검사이다. 대표적인 Corsi Block Test(CBT) 검사 형태 는 대략 공책 크기의 보드 위에 9 개의 블록을 놓은 후, 검사자 가 일정 순서대로 블록들을 짚어 나가면 피검자가 이를 기억 하여 순서대로, 혹은 거꾸로 되짚어 나가는 것이다. CBT 검사 의 순행, 역행 시행의 정반응수를 시공간 작업기억력 평가치 로 분석에 활용하였다. ${ }^{27)}$

\section{스마트 토이를 활용한 학령기 아동용 기억력 훈련 프로그램}

본 훈련 프로그램은 Toh 등 ${ }^{18}$ 이 일반 아동에게도 적용 가능 한 로봇을 활용한 훈련 영역 중 하나로 제안한 인지, 특히 기 억력을 주된 훈련 영역으로 설정하였다. 그리고 로봇의 특성 을 활용하여 기존의 일방향적인 지시에 따르는 수행방식과는 달리 아동과 상호작용이 가능하도록 고안하였다. Fig. 1과 같 이 스마트 토이의 눈 동작은 liquid crystal display를 이용하 여 출력하고, 입술 모양 light emitting diode가 동작되어 음 성으로 말할 시 자동으로 얼굴표정을 연출할 수 있다. 토이 본체에 장착된 태블릿을 통해 기억력 훈련 프로그램이 구현 되고, 아동은 화면을 터치함으로써 반응을 입력할 수 있다. 입력된 반응은 스마트 토이와 호환되고 정답 여부에 따라 적 시에 스마트 토이가 다양한 표정을 짓고, 팔을 움직이는 등의 피드백을 줄 수 있다. 예를 들어, 아동이 수행을 잘하거나 어 려움을 겪을 때 스마트 토이가 직접 아동에게 '잘했어’라고 칭 찬해주거나 위로하고 도움말을 제공할 수 있다. 이렇게 토이 가 아동에게 적극적인 피드백을 제공함으로써 아동의 훈련 참여도를 높이고 훈련의 효과를 극대화할 수 있게 하였으며, 더 나아가 스마트 토이가 훈련을 하는 임상가나 부모, 교사의 역할을 대신할 수 있도록 하였다. 또한 사용 대상이 초등학생 이라는 점을 고려하여 흥미를 유발하고 훈련 몰입도를 증진 시키기 위해 게임 형식을 차용하였으며, 아동의 능력과 수행 능력에 따라 적응적으로 조절되어 사용자가 해결 가능한 범 위 내에서 최대 수준까지 반복적으로 훈련하여 기억력과 작 업기억력을 최대한 향상시킬 수 있도록 고안되었다. 본 훈련 프로그램은 국내외 아동신경심리학자 및 임상심리전문가들

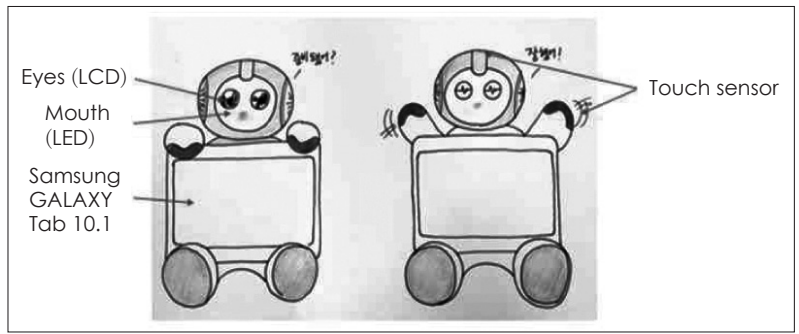

Fig. 1. Smart-toy.
의 자문을 통해 수정 및 보완 과정을 거쳤으며, 청각언어 기 억력, 시각공간 기억력, 청각언어 작업기억력, 시각공간 작업 기억력 과제 등 4가지 영역으로 구성되어 있다.

\section{청각언어 기억력 훈련과제}

본 과제는 청각적으로 제시되는 지시를 기억해 두었다가, 그 내용을 화면에서 찾아 하나씩 선택하는 청각언어 기억력 훈 련과제이다. 아동은 3 가지 장면(버스정류장, 집, 놀이동산)을 선택하여 훈련을 시작할 수 있고, 각 장면에서 청각적으로 제 시되는 지시를 잘 듣고 기억하여 이를 선택해야 한다. 찾아야 할 항목의 수(span)에 따라 난이도가 1 6단계로 구성된다. 난 이도 1단계에서는 두 가지 항목을 기억해야 하는데, 난이도가 한 단계씩 올라갈수록 기억폭(span)이 한 개씩 증가하여, 최 종 난이도에서는 7개의 항목을 기억해야 한다. 연속적으로 성 공하면 단서 아이템이 제공되어 수행을 더 잘하도록 도와줄 수 있고(보상), 연속적으로 실패할 경우 여러 가지 책략을 알려 주는 도움말이 제공된다. 하루에 5 회 시행하고, 한 번의 시행 당 1 2분이 소요되어, 총 $5 \sim 10$ 분이 소요된다. 측정치는 정반 응 수와 오반응 수, 시행점수, span 점수, 반응촉구 횟수이다.

\section{시각공간 기억력 훈련과제}

본 과제는 화면에 제시되는 시각정보(항목, 예: 동물, 소품 등) 및 공간정보 $($ 위치 $1 \times 2,1 \times 3,2 \times 2)$ 를 기억하여, 특정 위치 (공간)에 있었던 자극(시각)을 지적해야 하는 시각공간 기억력 훈련과제이다. 아동은 3 가지 장면(동물원, 레스토랑, 바다)을 선택하여 훈련을 시작할 수 있다. 과제는 '자극제시'와 '응답' 화면으로 구성되는데, 자극제시 단계에서는 공간자극의 여러 위치에 각기 다른 시각자극(예: 동물, 소품)이 위치해 있는 것 을 일정 시간 보여준다. 이후 구획화된 공간이 모두 닫히고 특정자리에 있었던 자극을 기억해 내도록 하는데 아동이 보기 에 제시되는 여러 가지 자극 중 목표자극을 골라서 터치하면 자동으로 자극이 조합되고, 이후 정답 여부를 확인하도록 피 드백이 제시된다. 각 장면은 공간자극과 시각자극의 수에 따 라 난이도가 1 12단계로 구성된다. 연속으로 성공하면 아이 템이 제공되고, 연속적으로 실패할 경우 여러 가지 책략을 알 려주는 도움말이 제공된다. 하루에 10회를 시행하여 총 5 10 분이 소요된다. 측정치는 정반응 수와 오반응 수, 시행점수, 반 응촉구 횟수이다. Fig. 2 는 시각공간 기억력 훈련과제의 화면 예시이다.

\section{청각언어 작업기억력 훈련과제}

본 과제는 단순한 조작을 요하는 게임을 하면서 청각적으로 제시되는 숫자를 기억했다가 이를 지시에 따라 더하거나, 짝수/ 


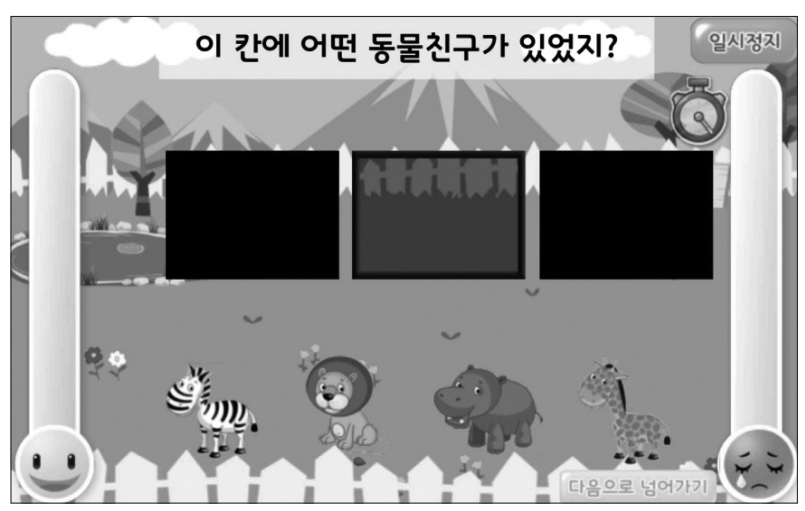

Fig. 2. The scene of visual-spatial memory training task.

홀수의 개수를 세어야 하는 청각언어 작업기억력 훈련과제이 다. 철인삼종경기 상황을 설정하여 아이템을 획득하고, 장애 물을 피하는 등의 경기에 임하는 동시에 경기 도중에 청각으 로 제시되는 숫자들을 기억했다가, 지시에 따라 응답하도록 구성되었다. 아동은 화면에 제시된 두 개의 레인을 오가며 장 애물(파도, 회오리, 미끄럼 등)을 피하거나 아이템(초콜릿)을 획득해야 하며, 동시에 청각적으로 제시되는 숫자를 기억해야 한다. 경기가 종료된 후, 제시되었던 숫자를 모두 더하거나, 짝 수/홀수의 개수를 세어 응답하도록 한다. 아동은 3가지 종목 (수영, 사이클, 마라톤)을 선택하여 훈련을 시작할 수 있고, 각 종목은 제시되는 숫자의 수에 따라 난이도 1 8단계로 구성된 다. 난이도 1 단계에서는 두 개의 숫자가 제시되며, 난이도가 한 단계 올라갈수록 기억폭이 1개씩 증가하여, 최종 난이도 8 단계에서는 9 개의 숫자가 제시된다. 경기 후 문제를 정확히 맞 히면 보상으로 메달이 제공된다. 연속적으로 성공하면 아이템 이 제공되고, 연속적으로 실패할 경우 여러 가지 책략을 알려 주는 도움말이 제공된다. 하루에 10회를 시행하여 총 6 8분 이 소요된다. 측정치는 시행점수와 결승점 통과까지 걸리는 시간이다.

\section{시각공간 작업기억력 훈련과제}

본 과제는 화면에 나타난 여러 개의 위치 중 문제로 제시되 는 특정 위치의 순서를 기억하여, 이후 순서대로(순행) 혹은 역 순(역행)으로 응답해야 하는 시각공간 작업기억력 훈련과제 이다. 아동은 3 가지 장면(식당, 마을, 캠핑장)을 선택할 수 있고, 각 상황에서 물건을 주문하는 사람들의 위치를 기억했다가 순서대로 혹은 역순으로 배달하도록 구성하였다. 과제는 '문 제제시'와 ‘응답’ 화면으로 구성되며, 문제가 제시되는 단계에 서는 화면상의 특정 공간에서 순차적으로 물건(콜라, 우유 등)을 주문한다. 이후 응답단계에서는 순서대로 공간을 선택 하여 물건을 배달하거나(forward 조건), 역순으로 공간을 선 택하여 배달해야 한다(backward 조건). 아동의 수행 정도에

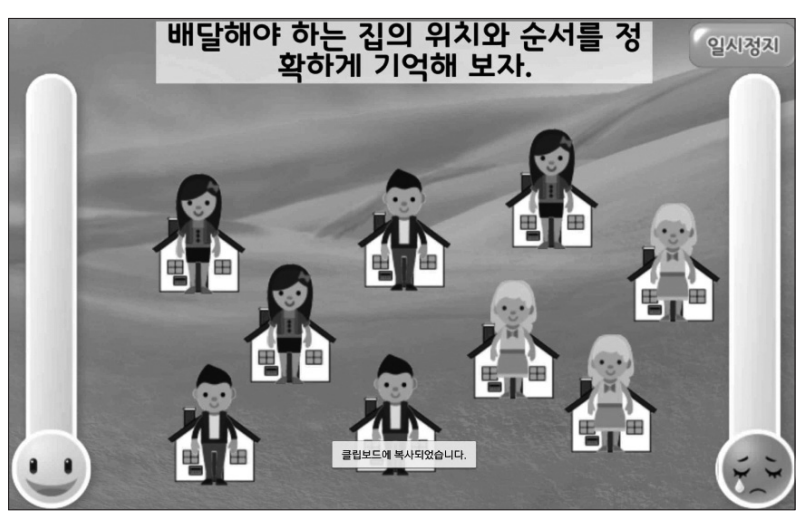

Fig. 3. The scene of visual-spatial working memory training task.

따라 공간자극이 9 개인 옵션과 12 개의 옵션이 있어 선택할 수 있다. 각 장면은 기억해야 할 자극의 수에 따라 난이도 1 7단 계로 구성된다. 난이도 1 단계에서는 두 명이 물건을 주문하 며, 난이도가 한 단계 올라갈수록 기억폭이 1 개씩 증가하고, 난이도 7단계에서는 8 개의 숫자가 제시된다. 연속적으로 성공 하면 아이템이 제공되고(보상), 연속적으로 실패할 경우 여러 가지 책략을 알려주는 도움말이 제공된다. 하루에 순행 조건 과 역행 조건을 각각 10회씩 시행하여 약 10 15분이 소요되며, 측정치는 시행점수(순행, 역행)와 기억폭 점수(순행, 역행)이다. Fig. 3 은 시각공간 작업기억력 훈련과제의 화면 예시이다.

\section{연구 절차}

본 연구는 서울대학교 의학연구윤리심의위원회의 승인을 받았으며, 모든 참여대상자와 부모에게 서면동의를 취득하였 다(IRB No. 1509-035-704). 이들은 모두 스마트 토이를 기반 으로 한 기억력 향상 프로그램에 4주 동안 8회기를 참여하였 고, 각 회기의 훈련은 숙련된 훈련자가 아동과 일대일로 짝을 이루어 진행하였다. 한 회기당 청각언어 기억력, 시각공간 기억 력, 청각언어 작업기억력, 시각공간 작업기억력 등 4가지 과제 를 각각 10 15분씩 총 45 분간 진행하였다. 또한 훈련 전후의 기억력 및 작업기억력을 평가함으로써, 훈련을 통해 기억력 및 작업기억력이 향상되었는지 검증하였다.

\section{자료분석}

본 연구에서 개발한 8 10세용 기억력 훈련과제가 실제로 아 동의 기억력을 향상시킬 수 있는지 검증하기 위해 SPSS 18.0 (SPSS Inc., Chicago, IL, USA)을 사용하였다. 훈련 전과 후에 실시한 검사 결과는, 1) 청각언어 기억력, 2) 시각공간 기억력, 3) 청각언어 작업기억력, 4) 시각공간 작업기억력의 4가지 영 역의 평균과 표준편차 점수로 산출하였다. 훈련 종료 이후에 나타난 점수변화가 통계적으로 유의미한지를 검증하기 위해 사전-사후 평균점수에 대하여 대응표본 t-test를 실시하였다. 


\section{결 과}

총 18 명 모두 훈련 전후에 평가를 받았다. 기억력 훈련과제 를 실시하기 전과 실시한 이후의 기억력 수행점수를 t-test를 통해 비교한 결과, 1) 청각언어 기억력, 2) 시각공간 기억력, 3) 청각언어 작업기억력, 4) 시각공간 작업기억력을 측정하는 주 요지표에서 기억력 훈련을 실시하기 전에 비해 실시한 이후에 수행이 유의미하게 향상되었다.

\section{청각언어 기억력 훈련과제의 효과}

청각언어 기억력 수행에 관한 사전사후 점수변화 및 t-test 통계치는 Table 2에 제시하였다. 분석결과, 스마트 토이웹 청 각언어 기억력 평가과제의 즉시회상 정반응수와 지연회상 정 반응수가 유의하게 증가하였다 $(\mathrm{t}=-4.35, \mathrm{p}<0.01 ; \mathrm{t}=-3.27, \mathrm{p}<$ 0.01). KEDI-WISC 숫자외우기 점수도 사전 검사에 비해 사 후검사에서 유의하게 증가하였는데, 이는 단순기억력이 유의 미하게 향상된 것을 의미한다 $(\mathrm{t}=-2.38, \mathrm{p}<0.05)$. 유사한 단어 목록 검사인 K-LNNB-C 128번 문항에서도 사전 검사에 비 해 사후검사에서 정반응수가 유의미하게 향상되었다 $(\mathrm{t}=-3.69$, $\mathrm{p}<0.01)$. 이는 기억력 훈련을 통해 언어적 학습능력과 청각언 어정보의 저장 및 인출능력이 향상된 것을 의미한다.

\section{시각공간 기억력 훈련과제의 효과}

시각공간 기억력 수행에 관한 사전사후 점수변화 및 t-test
통계치는 Table 3에 제시하였다. 분석결과, 스마트 토이웹 시 각공간 기억력 평가과제의 즉시회상 항목점수와 지연재인 정 반응수가 유의하게 증가하여 시각공간 기억의 정확도가 향상 된 것으로 나타났다 $(\mathrm{t}=-4.82, \mathrm{p}<0.01 ; \mathrm{t}=-4.22, \mathrm{p}<0.01)$. ROCF 검사의 즉시회상과 지연회상의 세부적 정확도가 사전 검사에 비해, 사후검사에서 유의미하게 향상되었다 $(\mathrm{t}=-4.17, \mathrm{p}<0.01$; $\mathrm{t}=-5.46, \mathrm{p}<0.01)$. 이는 훈련을 통해 시각적 정보의 저장능력 및 인출 효율성이 유의미하게 향상된 것을 의미한다.

\section{청각언어 작업기억력 훈련과제의 효과}

청각언어 작업기억력 수행에 관한 사전사후 점수변화 및 $\mathrm{t}-$ test 통계치는 Table 4에 제시하였다. 분석결과, KEDI-WISC 산수 검사의 원점수가 사전 검사에 비해, 사후검사에서 유의미 하게 향상되었다 $(\mathrm{t}=-2.41, \mathrm{p}<0.05)$. 이는 훈련을 통해 청각언어 적 작업기억능력이 향상된 것을 의미한다. 스마트 토이웹 청 각언어 작업기억력 평가과제의 점수변화는 유의하지 않았으 나 기억폭 점수와 정반응수는 증가하고 오반응은 감소하는 등 청각언어 작업기억이 향상되는 경향성은 확인할 수 있었다 $(\mathrm{t}=-1.33, \mathrm{p}=0.200 ; \mathrm{t}=-1.62, \mathrm{p}=0.124 ; \mathrm{t}=0.68, \mathrm{p}=0.508)$.

\section{시각공간 작업기억력 훈련과제의 효과}

시각공간 작업기억력 수행에 관한 사전사후 점수변화 및 $\mathrm{t}-$ test 통계치는 Table 5에 제시하였다. 분석결과, 스마트 토이웹 시각공간 작업기억력 평가과제의 순행 및 역행 시행점수가 유

Table 2. Changes in task performance of auditory-verbal memory before and after the training $(n=18)$

\begin{tabular}{|c|c|c|c|}
\hline \multirow{2}{*}{ Auditory-verbal memory task } & Pre & Post & \multirow{2}{*}{$\dagger$} \\
\hline & $M(S D)$ & $M(S D)$ & \\
\hline \multicolumn{4}{|l|}{ Smart toy-web auditory-verbal memory task } \\
\hline Immediate recall correct response & $21.89(4.85)$ & $26.22(4.57)$ & $-4.35^{\dagger}$ \\
\hline Delayed recall correct response & $8.28(1.93)$ & $9.78(1.96)$ & $-3.27^{\dagger}$ \\
\hline Delayed recognition correct response & $11.06(1.55)$ & $11.39(1.42)$ & -1.56 \\
\hline KEDI-WISC digit span & $11.39(2.99)$ & $13.83(2.87)$ & $-3.69^{\dagger}$ \\
\hline K-LNNB-C_memory scale (no.128) & $31.67(2.50)$ & $33.22(1.26)$ & $-2.38^{*}$ \\
\hline \multicolumn{4}{|c|}{$\begin{array}{l}\text { * } \mathrm{p}<0.05,{ }^{\dagger} \mathrm{p}<0.01 . \mathrm{K}-\mathrm{LNNB}-\mathrm{C}: \text { the Korean version of Luria-Nebraska Neuropsychological Test for Children, KEDI-WISC: Korea Edu } \\
\text { cational Development Institute Wechsler Intelligence Scale for Children, M: mean, SD: standard deviation }\end{array}$} \\
\hline \multirow{2}{*}{ Visual-spatial memory task } & Pre & Post & \multirow{2}{*}{$\dagger$} \\
\hline & $M(S D)$ & $M(S D)$ & \\
\hline \multicolumn{4}{|l|}{ Smart toy-web visual-spatial memory task } \\
\hline Immediate recall correct response & $38.39(12.33)$ & $57.94(23.71)$ & $-4.82^{*}$ \\
\hline Delayed recognition correct response & $16.94(3.23)$ & $19.33(1.03)$ & $-4.22 *$ \\
\hline \multicolumn{4}{|l|}{ ROCF } \\
\hline Immediate recall_incidental elements accuracy & $23.17(8.39)$ & $29.56(7.25)$ & $-4.17^{*}$ \\
\hline Delayed recall_incidental elements accuracy & $24.67(6.82)$ & $30.44(5.63)$ & $-5.46 *$ \\
\hline
\end{tabular}

*p<0.01. M: mean, ROCF: Rey-Osterrieth Complex Figure Test, SD: standard deviation 
Table 4. Changes in task performance of auditory-verbal working memory before and after the training $(n=18)$

\begin{tabular}{|c|c|c|c|}
\hline \multirow{2}{*}{ Auditory-verbal working memory task } & Pre & Post & \multirow{2}{*}{$\dagger$} \\
\hline & $M(S D)$ & $M(S D)$ & \\
\hline \multicolumn{4}{|l|}{ Smart toy-web auditory-verbal working memory task } \\
\hline Span & $6.00(2.70)$ & $6.89(2.11)$ & -1.33 \\
\hline Correct response & $7.11(4.24)$ & $8.67(4.26)$ & -1.62 \\
\hline Incorrect response & $2.44(1.10)$ & $2.22(1.44)$ & 0.68 \\
\hline KEDI-WISC arithmetic & $12.06(1.95)$ & $12.94(1.98)$ & $-2.41^{*}$ \\
\hline
\end{tabular}

${ }^{*} p<0.05$. KEDI-WISC: Korea Educational Development Institute Wechsler Intelligence Scale for Children, M: mean, SD: standard deviation

Table 5. Changes in task performance of visual-spatial working memory before and after the training $(n=18)$

\begin{tabular}{|c|c|c|c|}
\hline \multirow{2}{*}{ Visual-spatial working memory task } & Pre & Post & \multirow{2}{*}{$\dagger$} \\
\hline & $M(S D)$ & $M(S D)$ & \\
\hline \multicolumn{4}{|l|}{ Smart toy-web visual-spatial working memory task } \\
\hline Forward & $9.33(4.79)$ & $13.50(4.06)$ & $-3.83^{*}$ \\
\hline Backward & $7.61(3.57)$ & $11.28(3.88)$ & $-3.85^{*}$ \\
\hline \multicolumn{4}{|l|}{ Corsi Block Test } \\
\hline Forward & $8.06(2.18)$ & $9.67(1.75)$ & $-3.19 *$ \\
\hline Backward & $7.28(1.74)$ & $8.44(2.04)$ & -1.86 \\
\hline
\end{tabular}

${ }^{*} p<0.01$. M: mean, SD: standard deviation

의하게 증가하였고(t=-3.83, $\mathrm{p}<0.01 ; \mathrm{t}=-3.85, \mathrm{p}<0.01), \mathrm{CBT}$ 순행 시행점수가 사전 검사에 비해, 사후검사에서 유의미하게 향상되었다 $(\mathrm{t}=-3.19, \mathrm{p}<0.01)$. 이는 훈련을 통해 시각공간 작 업기억능력이 유의미하게 향상되었음을 보여주는 결과이다.

\section{고 찰}

본 연구에서는 스마트 토이를 매개로 한 인지훈련 프로그 램이 전반적으로 인지능력 향상에 도움이 되는지에 대해 검 증하고자 하였다. 사전, 사후검사 결과를 비교한 결과, 청각언어 기억력, 시각-공간 기억력, 시각-공간 작업기억력에서 훈련 후에 유의미한 향상이 확인되었다. 첫째, 스마트 토이웹 청각언어 기억력 훈련과제를 실시하기 전과 실시한 이후의 청 각언어 기억 검사의 수행을 비교해 본 결과, 기억력 훈련을 통 해, 언어적 학습능력과 청각언어정보의 저장 및 인출능력이 향상되었으며 청각적 기억폭이 넓어지고 단순 기억능력도 향 상되었음을 확인할 수 있었다. 또한 스마트 토이웹 시각공간 기억력 훈련과제를 실시하기 전에 비해 훈련 후 단순한 시공 간적 정보의 저장능력 및 인출 효율성이 향상되었다. 아울러 스마트 토이웹 시공간 기억력 훈련과제 역시 시각공간 작업기 억력의 유의미한 향상을 가져오는 것으로 나타났다. 이러한 결과들은 청각언어 기억력과 시각공간 기억력, 시각공간 작업 기억력이 체계적인 인지훈련을 통해 향상될 수 있음을 보여준 기존의 연구 결과와 일치한다. ${ }^{4,5,13)}$ 다만 대부분의 연구에서 단순한 기억의 유지를 훈련하는 경우 실행 기능으로의 전이
효과가 거의 나타나지 않았던 것에 비해, 본 연구에서는 단순 히 시각 기억의 위치를 기억하는 과제를 훈련하였음에도 계획 및 조직화 능력과 같은 복잡한 실행 기능을 요하는 ROCF 과 제의 수행이 유의미하게 향상되었다. ${ }^{28,29)}$ 기존의 연구 결과를 고려하면, 시공간적 조직화 능력과 같은 보다 복잡한 작업기 억력에 대한 훈련이 함께 제공되어 실행 기능으로의 전이효과 가 나타난 것일 가능성이 있다. 다만 이를 확인하기 위해서는 훈련집단을 시각공간 기억력과 시각공간 작업기억력을 별도 로 훈련하는 집단으로 나누고, 이들의 실행 기능으로의 전이 효과를 비교하는 추가적인 연구가 필요해 보인다. 또한 스마트 토이웹 청각언어 작업기억 훈련과제를 실시하기 전에 비해 훈 련과제 실시 후, $\mathrm{KEDI}-\mathrm{WISC}$ 검사의 산수 소검사에서는 유 의미한 향상이 확인되었지만, 스마트 토이웹 청각언어 작업기 억력 평가 과제의 점수변화는 유의미하지 않았다. 다만 기억 폭과 정반응수는 증가하고 오반응은 감소하여, 청각언어 작업 기억이 향상되는 경향성은 확인할 수 있었다. 다른 영역에 비 해 청각언어 작업기억력의 훈련 효과가 뚜렷하지 않았던 것은 본 연구가 정상 아동들을 대상으로 하여 훈련 전에도 작업기 억력의 손상이 크지 않았기 때문일 수 있다.

본 연구에서 개발한 인지기능 증진 프로그램은 다음과 같은 의의를 가진다. 첫째, 본 연구에서는 기존의 기억력 훈련 프로 그램의 제한점을 보완한 과제를 개발하여 기억력 및 작업기억 력 향상을 체계적으로 도모하고자 하였다. 단순히 뇌의 활성 화 수준을 변화시키는 것이 아니라, 과제 영역을 세분화하고 신경인지능력의 발달적 경향성을 고려하여 8 10세 학령기에 
학습이 효율적으로 이루어지기 위해 가장 중요하게 요구되는 기억력 및 작업기억력 증진을 목표로 하여 훈련을 제공하였 다. 둘째, 본 훈련 프로그램은 훈련 절차가 자동화되어 가정 및 학교 내에서도 손쉽게 아동의 기억력 및 작업기억력을 평 가하고, 훈련할 수 있다는 장점이 있다. 이를 통해 일반 아동들 이 직접 전문 교육 및 치료 기관을 방문하지 않고도 인지기능 을 향상시킬 수 있는 기회의 폭이 확대될 수 있을 것으로 예 상된다. 셋째, 아동들이 흥미를 가지고 친근하게 접근할 수 있 는 로봇 형태의 스마트 토이라는 새로운 디바이스를 고안하 고, 콘텐츠 면에서도 게임의 요소를 도입하여, 훈련 주체인 아 동이 흥미를 오래 지속할 수 있도록 하였다. 아울러, 스마트 토이가 간단한 동작과 음성, 표정 등을 통해 정서적이고 사회 적인 피드백을 제공할 수 있도록 고안하여 기억력의 발달뿐만 아니라 정서 및 사회적 능력의 발달에도 긍정적인 영향을 줄 수 있을 것으로 기대된다. 또한, 스마트 기기를 활용함으로써 기존의 전산화된 프로그램에 비해 업데이트나 다양한 영역으 로의 확장이 용이하다는 장점도 있다.

그러나 본 연구는 예비연구로 진행된 것이므로, 몇 가지 방법 론적 제한점이 있다. 첫째, 본 연구에서는 비교집단과 대기집 단이 포함되지 않았다. 이에 스마트 토이웹 훈련 프로그램 시 행 전후의 기억력의 변화가 시간의 경과에 따른 인지능력의 발 달 때문인지, 혹은 과제의 특성이나 자극에 익숙해졌기 때문 인지(학습 효과)를 구분하기 어렵다는 제한점이 있으며, 추가 적으로 기존에 개발된 타 훈련 프로그램에 비해 우수한지 역 시 확인하기 어려웠다. 둘째, 성과 연령에 따라 인지능력의 발 달에 차이가 있지만, 본 연구에서는 개발한 과제의 훈련 효과 를 예비적으로 검증하는 차원에서 필요한 최소 인원수만 연 구 대상으로 포함하였기 때문에 어떤 훈련과제가 어느 연령 대와 성별에서 더 효과적인지를 통계적으로 확인하기는 어려 웠다. 셋째, 본 연구는 흔히 작업기억력에 문제가 있는 것으로 알려진 ADHD나 학습 장애 아동들을 포함시키지 않았기 때 문에 주의력 및 학습 문제를 보이는 고위험군 아동에 대해서 도 동일한 효과가 나타는지에 대한 추가적인 연구가 반드시 필요해 보인다. 따라서 향후 다양한 임상 집단 및 통제집단을 포함하여, 충분한 연구 대상자를 대상으로 본 연구의 결과를 재확인하는 연구가 수행되어야 할 것이다. 마지막으로, 인지 훈련으로 인한 효과가 훈련 후에도 오래 지속되고, 훈련되지 않은 다른 인지 영역이나 실생활로 전이되는지는 인지훈련의 효과성 연구에 있어 매우 중요한 부분이지만 이에 대한 기존 의 연구 결과들은 서로 불일치한 결과를 보이고 있다.,12,13) 따 라서 후속 연구에서는 추후 평가를 통해 향상된 인지능력이 장기적으로 유지되는지와 향상된 기억력 및 작업기억력이 실 행 기능과 같이 직접적으로 훈련되지 않는 다른 인지 영역이
나 실질적인 학업성취의 향상으로 전이되는지에 대해서도 확 인할 필요가 있겠다.

\section{결 론}

본 연구에서 개발한 인지기능 증진 프로그램은 스마트 토 이가 아동과 상호작용을 하며 피드백을 제공함으로써 간편하 게 기억력 및 작업기억력 훈련을 진행할 수 있도록 고안되었 다. 인지훈련 프로그램을 수행한 전과 후의 인지기능의 변화 를 기존의 평가 도구 및 스마트 토이웹 평가 도구를 통해 비 교해 본 결과, 본 프로그램은 8 10세 아동들의 청각-언어 기 억력 및 작업기억력과 시각-공간 기억력 및 작업기억력을 향 상시키는 것으로 나타났다. 본 프로그램은 과제의 실시와 결 과 제시가 자동화되어 있어 전문가의 도움 없이 가정 및 학교 에서도 인지훈련을 진행하는 것이 가능하다는 장점이 있다. 아울러 게임의 요소를 도입하고 정서적, 사회적인 피드백을 제공하여 아동의 과제에 대한 흥미나 동기를 유지시키고, 기 억력 및 작업기억력의 향상뿐만 아니라 기존의 스마트 디바이 스 활용의 문제점으로 지적된 일방향적 의사소통으로 인한 부정적인 영향을 감소시킬 수 있을 것으로 기대된다.

중심 단어: 스마트 토이; 기억력; 작업기억력;

인지훈련 프로그램; 학령기 아동.

\section{Acknowledgments}

본 기억력 평가과제의 개발은 대한민국 산업통상자원부의 지원을 받아 이루어졌음(과제명: 완구산업 활성화를 위한 스마트 ToyWeb 서 비스 기술개발, 과제번호: 10045351).

\section{Conflicts of Interest}

The authors have no financial conflicts of interest.

\section{REFERENCES}

1) Isaacs EB, Vargha-Khadem F. Differential course of development of spatial and verbal memory span: a normative study. Br J Dev Psychol 1989;7:377-380.

2) Kim YH, Cho SC, Shin MS. Comparison of memory function between attention deficit/hyperactivity disorder and learning disorder children. J Korean Acad Child Adolesc Psychiatry 2002;13:85-92.

3) Alloway TP, Gathercole SE, Kirkwood H, Elliott J. The cognitive and behavioral characteristics of children with low working memory. Child Dev 2009;80:606-621.

4) Klingberg T. Training and plasticity of working memory. Trends Cogn Sci 2010;14:317-324.

5) Melby-Lervåg M, Hulme C. Is working memory training effective? A meta-analytic review. Dev Psychol 2013;49:270-291.

6) Silva ED, Macedo M, Teixeira C, Lanzer E, Graziani ÁP. Gamebased learning: analysis of students' motivation, performance, and drop out in a production engineering course. In: Kantola JI, Barath T, Nazir S, Andre T, editors. Advances in human factors, business management, training and education. New York: Springer International Publishing;2017. 
7) Ninaus M, Pereira G, Stefitz R, Prada R, Paiva A, Neuper C, et al. Game elements improve performance in a working memory training task. Int J Serious Games 2015;2:3-16.

8) Chancellor B, Chatterjee A. Brain training. In: Chatterjee A, Farah MJ, editors. Neuroethics in practice. New York: Oxford University Press;2013. p.57.

9) Swanger MM. Using a computerized program to improve working memory in intermediate school students [dissertation]. Ashland: Ashland University;2013.

10) Dewan NA, Luo JS, Lorenzi NM. Mental health practice in a digital world. New York: Springer International Publishing;2015.

11) Park MY, Park SM, Cho SZ, Shin MS. The effect of CBT-based training using computer games for ADHD children. Korean J Clin Psychol 2010;29:639-657.

12) Shipstead Z, Hicks KL, Engle RW. Cogmed working memory training: does the evidence support the claims? J Appl Res Mem Cognit 2012;1:185-193.

13) Klingberg T, Fernell E, Olesen PJ, Johnson M, Gustafsson P, Dahlström K, et al. Computerized training of working memory in children with ADHD--a randomized, controlled trial. J Am Acad Child Adolesc Psychiatry 2005;44:177-186.

14) Chacko A, Bedard AC, Marks DJ, Feirsen N, Uderman JZ, Chimiklis A, et al. A randomized clinical trial of cogmed working memory training in school-age children with ADHD: a replication in a diverse sample using a control condition. J Child Psychol Psychiatry 2014; $55: 247-255$.

15) Lee MJ, Honh SJ, Shin GH, Kim CB. Developmental and pilot-study of the working memory training program for children. J Soc Sci 2015; 26:27-44.

16) Drigas A, Kokkalia G. Mobile learning for special preschool education. Int $\mathrm{j}$ Interact Mob Technol 2016;10:60-67.

17) FernáNdez-LóPez Á, RodríGuez-FóRtiz MJ, RodríGuez-Almendros ML, MartíNez-Segura MJ. Mobile learning technology based on iOS devices to support students with special education needs.
Comput Educ 2013;61:77-90

18) Toh LPE, Causo A, Tzuo PW, Chen IM, Yeo SH. A review on the use of robots in education and young children. Educ Technol Soc 2016; 19:148-163.

19) Beran TN, Ramirez-Serrano A, Kuzyk R, Fior M, Nugent S. Understanding how children understand robots: perceived animism in child-robot interaction. Int J Hum Comput Stud 2011;69:539-550.

20) Robins B, Dautenhahn K, Te Boekhorst R, Billard A. Robotic assistants in therapy and education of children with autism: can a small humanoid robot help encourage social interaction skills? Univers Access Inf Soc 2005;4:105-120.

21) Kibot 2 [cited 2017 Dec 15]. Available from: http://kibot2.olleh.com.

22) Atti [cited 2017 March 10]. Available from: http://www.sktelecom. com/press/detail.do?idx $=2882$.

23) Shin MS, Lee J, Eo Y, Oh S, Lee J, Kim I, et al. The development and validation of memory tasks using smart devices for school aged children. J Korean Acad Child Adolesc Psychiatry 2016;27:130-138.

24) Park K. KEDI-WISC Manual. Seoul: Korean Educational Institute; 1991.

25) Shin MS. Standardization study for the Korean version of the LuriaNebraska Neuropsychological Battery for Children I: scale construction, reliability \& norms for the Korean version of LNNB-C. J Korean Acad Child Adolesc Psychiatry 1994;5:54-69.

26) Shin MS, Koo HJ, Kim SK. Korean developmental scoring system for the Rey-Osterrieth Complex Figure. Seoul: Mindpress;2009.

27) Berch DB, Krikorian R, Huha EM. The Corsi block-tapping task: methodological and theoretical considerations. Brain Cogn 1998;38: 317-338.

28) Chein JM, Morrison AB. Expanding the mind's workspace: training and transfer effects with a complex working memory span task. Psychon Bull Rev 2010;17:193-199.

29) Wager TD, Smith EE. Neuroimaging studies of working memory: a meta-analysis. Cogn Affect Behav Neurosci 2003;3:255-274. 